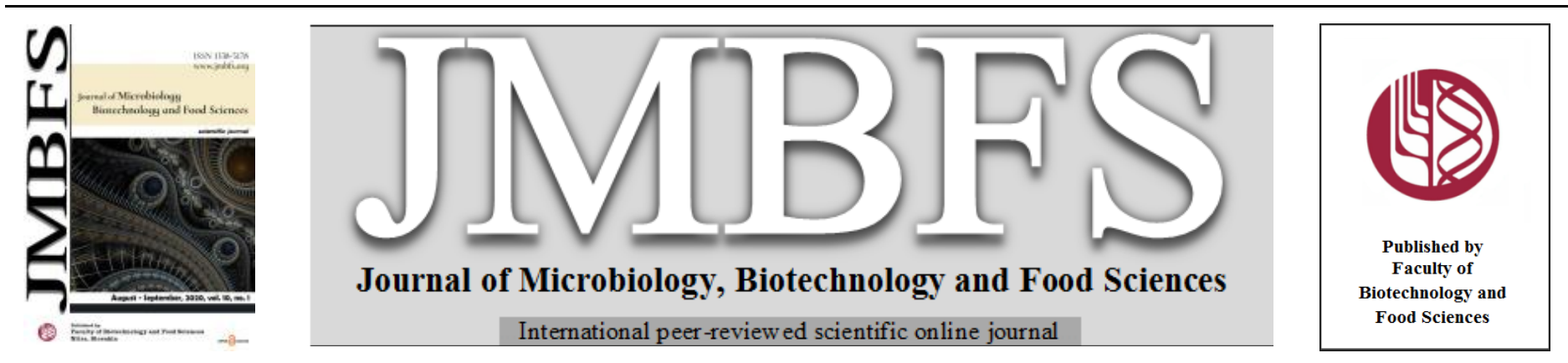

\title{
EVALUATION OF GENOTOXICITY OF THREE FOOD PRESERVATIVES IN DROSOPHILA MELANOGASTER USING SMART AND COMET ASSAYS
}

\author{
Ingy El-Hefny ${ }^{* 1}$, Walaa Hozayen ${ }^{2,3}$, Neima AlSenosy ${ }^{4}$,Wesam Basal ${ }^{5}$, Amr Ahmed ${ }^{2}$, and Ayman Diab ${ }^{1}$
}

Address(es):

${ }^{1}$ October University for Modern Sciences and Arts, (MSA), Faculty of Biotechnology, Wahat Road, $6^{\text {th }}$ of October City, Egypt, Tel: $+201276243198 /+201225125141$.

${ }^{2}$ Beni-Suef University, Faculty of Postgraduate Studies for Advanced Sciences, Department of Biotechnology and Life Sciences, Beni-Suef, Egypt.

${ }^{3}$ Beni-Suef University, Faculty of Science, Biochemistry Division, Chemistry Department, Beni-Suef, Egypt.

${ }^{4}$ Ain Shams University, Faculty of Agriculture., Department of Genetics, Shubra el-Kheima, Egypt.

*Corresponding author: ingyelhefny@hotmail.com

doi: 10.15414/jmbfs.2020.10.1.38-41

ARTICLE INFO

Received 28. 11. 2018

Revised 2. 3. 2020

Accepted 4. 3. 2020

Published 1. 8. 2020

Regular article

open 2 access

\section{ABSTRACT}

The continuously growing food and beverage industry relies on food additives as a main component in their products. Such increased reliance on processed food, lead to neglectance of the harmful effects of the food additives on human health; among these are hypersensitivity, allergic reactions, genotoxicity, mutagenicity and more. This study investigates genotoxic effects of three food preservatives commonly consumed in daily meals; sodium sulphite, boric acid, and benzoic acid using the somatic mutation and recombination test (SMART) and comet assay in Drosophila melanogaster system. All of the tested compounds showed significantly high levels of tumor induction and frequency compared to a negative control in SMART assay. They also showed high amount of DNA damage in the comet assay indicating their high potential of being genotoxic materials.

Keywords: mutagenic, genotoxic, comet, Drosophila, food additives

\section{INTRODUCTION}

Food additives are substances frequently added to food to enhance the quality of the final product in several aspects; extending life time by retarding or inhibiting growth of microorganisms, colouring, sweetening, flavouring and thickening (Rekha and Dharman, 2011). For a long time, no observed adverse effects had been proven on the basis of toxicological studies. However, several studies had proven that the consumption of some additives in processed food might have increased the risk of human cancer despite the respected legal limits of these additives by the manufactures. The carcinogenic risk of food additives can be attributed to various factors; interaction of additives with some food ingredients, chemical formula of food additives might be changed during food processing to a carcinogenic formula, a negative synergistic effects when combined with other additives, unsuitable storage conditions, and unknown carcinogenic by-products occurring during the food processing (Gülsoy et al., 2015).

Sodium sulphite, a preservative used to stop the browning and further ripening of fruits, was found to induce inhibition of DNA synthesis in Vicia faba root, bridges in anaphase and chromatin erosion of interphase nuclei (Njagi and Gopalan, 1982).

According to (Olorunfemi et al., 2012), tests carried out at cytogenetic anomalies Allium cepa reveals a decrease of the mitotic index caused by treatments applied. Mitosis analysis indicates the development of a number of structural chromosomal aberrations and interphasis aberrations identified in the different stages of mitosis, the process of cell division being significantly affected.

Benzoic acid, a commonly used preservative as antimicrobial substance in many food products, was found to cause a weak positive increase in chromosomal aberration test in CHO cells (Ishidate et al., 1984). It also induced somatic mutations in Drosophila SMART test (Sarikaya and Solak, 2003) and increased the chromosomal aberration, sister chromatid exchange, and micronucleus frequency in human peripheral lymphocytes (Yilmaz et al., 2009; Al-Tai $\boldsymbol{e t}$ al., 2014).

Boric acid, an effective preservative against yeast and bacteria, inhibited the proliferation of prostate cancer cell lines, DU-145, and $\mathrm{LNCaP}$, in a dosedependent manner. It also inhibited non-tumorigenic prostate cell lines, PWR-1E, and RWPE-1, and the cancer cell line PC-3, but required higher concentrations than observed in human blood levels. It stimulated cell death independent proliferative inhibition, with little effect on cell cycle stage distribution and mitochondrial function in DU-145 cell line, (Barranco and Eckhert, 2004). Borax, a salt of boric acid, had an inhibitory effect on HepG2 cell growth and induced apoptosis in a concentration-dependent manner (Wei et al., 2016).

Among the most accepted tests that are applied to assess the carcinogenic potential of a given substance is the Somatic Mutations and Recombination Test (SMART) carried out in Drosophila melanogaster (Demir et al., 2013). This assay uses tumor suppressor gene warts which is a homolog to the mammalian tumor suppressor gene LATS (Nepomuceno, 2015; Vasconcelos et al., 2017). The evolutionary conservation of tumor suppressor genes among Drosophila and mammals has prompted studies of tumor induction in Drosophila, such studies has contributed to the understanding of cancer in human (Potter et al., 2000; Eeken et al., 2002)._Homozygosity loss of the warts gene induced by mitotic recombination in somatic cells leads to the formation of greatly overgrown cell clones that can be easily detected as tumors on fly body (justice et al., 1995) SMART is a rapid, very sensitive to different classes of agents and inexpensive assay which is able to evaluate the carcinogenic activity of single compounds as well as complex mixtures. It also allows various protocols for the application of the test materials as single, combined or sequential treatments of the larvae. Factors capable of Inducing tumors in Drosophila instead of marker clones might directly adverse the risk of these factors for inducing cancer in humans (Sidorov et al., 2001). In flies heterozygous for the wts gene, the genetic events that can lead to the tumor appearance and hence can be detected by SMART include; gene mutations in the wts gene, multilocus-deletions (partial), chromosomal loss and somatic recombination collectively referred to as loss of heterozygosity (Eeken et al., 2002).

Comet assay (also called, single cell gel electrophoresis, SCGE) is an assay used over the last few decades to detect any prospective damage for DNA after certain treatments. The assay is able to detect DNA strand breaks and alkali labile sites by measuring the migration of DNA from immobilized nuclear chromatin. This assay is one of the most widely accepted tests for detection of DNA damage as it offers several advantages over the other tests, these include: (1) damage to the DNA in individual cells is measured; (2) only small number of cells are needed to carry out the assay $(<10,000)$; (3) the assay can be performed on virtually any eukaryotic cell type; (4) and it is faster and more sensitive than the alkaline elution method for detecting DNA damage DNA (Singh $\boldsymbol{e t}$. al, 1988). Comet assay is a useful tool for the evaluation of local genotoxicity, particularly organs or cell types, which can hardly be evaluated with other standard tests (Brendler et al., 2005). Thist assay has become the prime choice in the assessment of DNA 
damage and genotoxicity testing considering that it is an easy to perform, short time and low cost test that requires small numbers of cells/sample. Moreover, it is sensitive for detecting low levels of DNA damage. Alkaline comet assay $(\mathrm{pH}>13)$, the most commonly used version, is able to detect all possible kinds of DNA damage (Tice et al., 2000). In recent years, the comet assay has been adapted to use in vivo in Drosophila (Mukhopadhyay et al., 2004; Shukla et al., 2011), to combine its advantages with those well-established of this fly.

The objective of this study was to evaluate the genotoxic and carcinogenic effects of three food additives; sodium sulphite, boric acid, and benzoic acid using SMART and comet assays in Drosophila.

\section{MATERIAL AND METHODS}

\section{Somatic Mutation and Recombination Test (SMART) in D. melanogaster}

\section{Drosophila Mealnogaster strains}

Two different Drosophila strains were used in this study; wild type strain and a strain that carries $w t s M T^{4-1}$, a lethal warts allele balanced on TM3, characterized by multiple inversions and marked by the dominant mutation stubble according to Eiken et al., (2002) and fly base (2006). The genetic structure of this strain is; st $\mathrm{p}$ in $r i$ wtsMT4-1/TM3 Sb, which was abbreviated wts/TM3. Details about the various markers and the balancer chromosome can be found in Lindsley and Zimm (1992).

\section{Crosses and treatments}

The wts/TM3 females were crossed to wild type males resulting in two genotypes offspring, wts/+ and TM3, Sb $\mathrm{wts}^{+/+}$. After 2 days, the parental flies were removed and 56-68 hours old larvae were washed with $20 \%$ glycerol, then collected using a fine mesh sieve and transferred to five different vials representing the five test groups. For food additives treated groups (Sodium sulphite, Boric acid, and Benzoic acid); the flies were transferred to a standard Drosophila medium to which a $100 \mathrm{mM}$ of each food additive powder was added and properly dissolved at $50^{\circ} \mathrm{C}$. The larvae were submitted to chronic treatment for approximately $48 \mathrm{~h}$., then they were transferred to standard Drosophila medium. The positive control group was transferred to a vial where $20 \mu \mathrm{g} / \mathrm{ml}$ of an appropriate Mitomycin C (MMC) solution was mixed with a standard Drosophila medium, kept for 24 hours, then they were transferred to standard Drosophila medium. Negative control group was directly transferred to a standard Drosophila medium. Afterwards, larvae of all groups were left to feed on the medium until completion of their development when they leave the medium and pupate. All Drosophila stocks and crosses were maintained at $25^{\circ} \mathrm{C}$ Only adult flies, without the chromosome balancer (TM3, Sb) with no truncated bristles were analysed.

\section{Scoring of Warts:}

After metamorphosis, the adult flies were transferred to flasks containing $70 \%$ ethanol. Flies were analysed for tumor presence using a Leica stereomicroscope used at a standard magnification of $25 \mathrm{X}$ and an entomological tweezers. Only tumors that were large enough to be unequivocally classified are recorded (Eeken et al., 2002).

\section{Statistical Analysis}

The tumor frequency was calculated as the number of tumors/number of $w_{t s}{ }^{+} /+$ flies (Eeken et al., 2002), while tumor induction was calculated as Number of tumors/ Number of tumor flies. The statistical assessment of the gentotoxic potential from tested compounds was identified by the Mann, Whitney and Wilcoxon nonparametric $U$ test, using $\alpha=0.05$ level of significance.

\section{DNA fragmentation by comet assay (single cell gel electrophoresis, SCGE)}

Extent of DNA strand breaks in all types of cells of the isogenic strain $\mathrm{w}^{1118}$ of Drosophila melanogaster were assessed using the alkaline comet assay in adult flies developed from both the untreated (control) and the $2^{\text {nd }}$ instar larvae treated for $24 \mathrm{~h}$ with the three tested compounds, basically as described by Singh $\boldsymbol{e t}$ al. (1988). Around 100 adult flies frozen in liquid nitrogen were gently homogenized into powder, and then an alkaline comet assay as described by Tice $\boldsymbol{e t}$ al., (2000) was utilized. $1 \mathrm{~g}$ of crushed samples were transferred to $1 \mathrm{ml}$ ice-cold PBS. This suspension was stirred for $5 \mathrm{~min}$ and filtered. Cell suspension $(100 \mu 1)$ was mixed with $600 \mu 1$ of low-melting agarose (0.8\% in PBS). $100 \mu 1$ of this mixture was spread on pre-coated slides. The coated slides were immersed in lyses buffer (0.045 M TBE, $\mathrm{pH} 8.4$, containing $2.5 \%$ SDS) for $15 \mathrm{~min}$. The slides were placed in electrophoresis chamber containing the same TBE buffer, but devoid of SDS. The electrophoresis conditions were $2 \mathrm{~V} / \mathrm{cm}$ for $2 \mathrm{~min}$ and $100 \mathrm{~mA}$. Staining with ethidium bromide $20 \mu \mathrm{g} / \mathrm{ml}$ at $4^{\circ} \mathrm{C}$. The observation was with the samples still humid, the DNA fragment migration patterns of 100 cells for each dose level were evaluated using Axio fluorescence microscope (Carl Zeiss, Germany) with an excitation filter of $524 \mathrm{~nm}$ and a barrier filter of $605 \mathrm{~nm}$. The comets tails lengths were measured from the middle of the nucleus to the end of the tail with $40 \mathrm{x}$ increase for the count and measure the size of the comet. Komet 5 image analysis software developed by Kinetic Imaging, Ltd. (Liverpoo1, UK) linked to a CCD camera was used to assess the quantitive and qualitative extent of DNA damage in the cells by measuring the length of DNA migration and the percentage of migrated DNA. Finally, the program calculates tail moment. Generally, 50 to 100 randomly selected cells are analyzed per sample.

\section{RESULTS AND DISCUSSION}

Detection of mutagenic Agents Using Somatic Mutation and Recombination Test (SMART) in D. melanogaster

The F1 generation of the crossed flies was divided into five treatment groups: a negative control group transferred to basic drosophila medium, positive control group transferred to a medium containing $20 \mu \mathrm{g} / \mathrm{ml} \mathrm{MMC)}$ and three treatment groups each was transferred to a medium containing $100 \mathrm{mM}$ of one of the tested compounds; sodium sulphite, boric acid and benzoic acid.

The frequency of tumors in $w t s /+$ negative control flies was 0.07 i.e., 7 flies with one warts per each 100 scored flies. Tumor induction in the negative control was also low (1.1). On the other hand, MMC treatment recorded the highes frequency 1.33 associated with the highest tumor induction (2.18). These tumors were detected in every part of the examined flies.

Comparing the effect of the tested food additives to the negative control showed that: both sodium sulphite and benzoic acid showed statistically significant increase in the frequency of warts tumor, while Boric acid treatment showed highly significant increase in tumor frequency Table (1). Tthe tumor induction of spontaneous and induced warts Epithelial tumors in $+/ w t s$ flies after treatments can be arranged in descendant manner as Mitomycin C (MMC), Boric acid, Sodium sulphite and Benzoic acid (Fig. 1)

Table 1 Frequencies of induced tumor in trans-heterozygous (wts/+) after larvae feeding treatments with three concentrations of Sodium sulphite, Boric acid, and Benzoic acid compared with the MMC as a positive control and negative control.

\begin{tabular}{|c|c|c|c|c|c|}
\hline Treatments & $\begin{array}{l}\text { Total No. of Fly } \\
\text { Scored }\end{array}$ & $\begin{array}{l}\text { No. of Fly Scored } \\
\text { with Tumor }\end{array}$ & $\begin{array}{l}\text { No. of } \\
\text { Tumor } \\
\text { Scored }\end{array}$ & $\begin{array}{l}\text { Tumor } \\
\text { Induction }\end{array}$ & $\begin{array}{l}\text { Frequency (No. of } \\
\text { Tumors/fly } \pm \text { S.D.) }\end{array}$ \\
\hline Negative Control & 950 & 61 & 69 & 1.1 & $0.07 \pm 0.06$ \\
\hline $\begin{array}{l}\mathrm{MMC} \\
20 \mu \mathrm{g} / \mathrm{ml}\end{array}$ & 765 & 465 & 1016 & 2.18 & $1.33 \pm 0.45$ \\
\hline $\begin{array}{l}\text { Sodium Sulphite } \\
\text { 100mM }\end{array}$ & 682 & 305 & 474 & 1.55 & $0.69 \pm 0.11 *$ \\
\hline $\begin{array}{l}\text { Boric Acid } \\
100 \mathrm{mM}\end{array}$ & 601 & 291 & 486 & 1.67 & $0.8 \pm 0.14 * *$ \\
\hline $\begin{array}{l}\text { Benzoic Acid } \\
\text { 100mM }\end{array}$ & 800 & 490 & 590 & 1.2 & $0.73 \pm 0.18^{*}$ \\
\hline
\end{tabular}




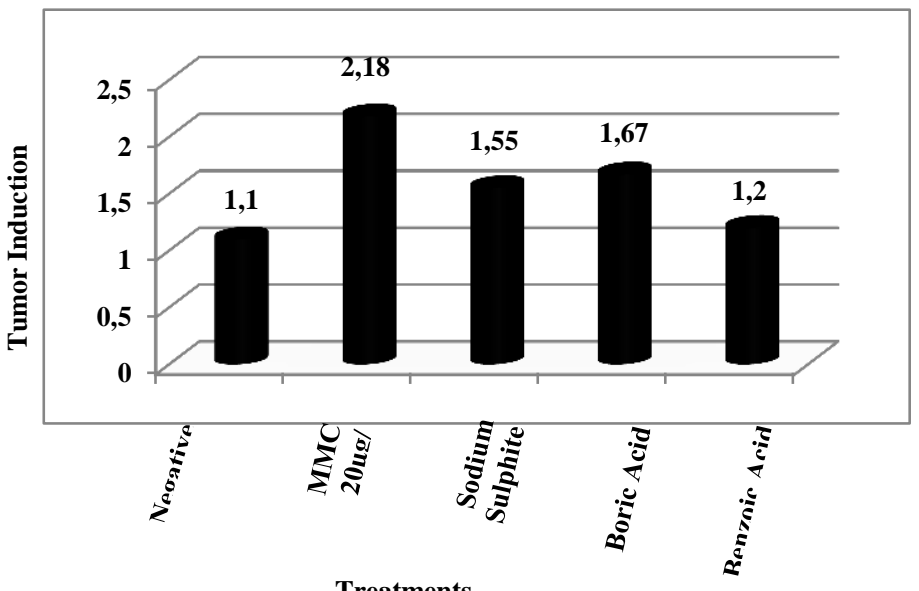

Treatments

Figure 1 Diagram represents the tumor induction of spontaneous and induced warts Epithelial tumors in $+/ w t s$ flies after treatments with Mitomycin C (MMC), Sodium sulphite, Boric acid, and Benzoic acid.

\section{DNA fragmentation by comet assay (single cell gel electrophoresis, SCGE)}

DNA damage was assessed in adults of the homogenic Drosophila strain $w^{1118}$ emerged from $2^{\text {nd }}$ larval instar exposed to three tested compounds. According to DNA damage parameters; tailed\%, untailed \%, tails length, tail DNA\% and tail moment, all of the three tested salts caused significant DNA damage Table(2). Moreover, an increase in tail length was observed in sodium sulphite, boric acid and benzoic acid treated groups as compared to control group (Fig. 2), which is a clear indication on DNA degradation and strand breaks. Migration length is considered to be directly related to fragment size and proportional to the level of single stranded breaks and alkali-labile sites (Tice $\boldsymbol{e t}$ al., 2000).

Benzoic Acid had significantly higher deleterious effect on DNA of $D$. melanogaster $(8.5 \pm 0.58 \mu \mathrm{m}$ compared with control $1.29 \pm 0.10)$ than Sodium

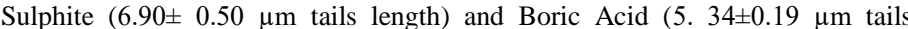
length). Tail DNA percentage was $1.45 \%$ in control, $7.11 \%$ in Benzoic Acid treatment, $5 \%$ in Sodium Sulphite treatment and $4.15 \%$ in Boric Acid as recorded in Table (2).
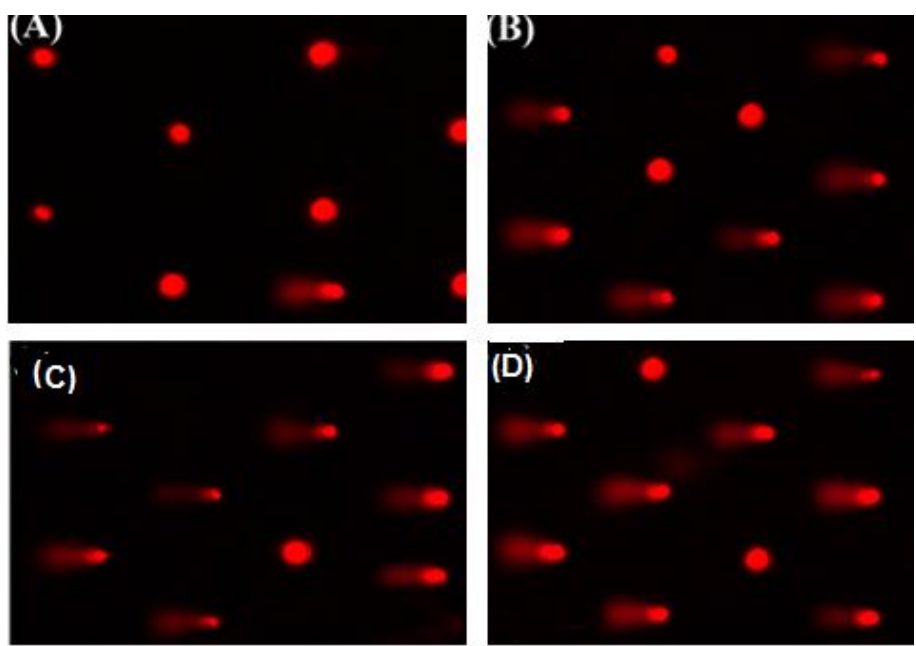

Figure 2 DNA damage in adult Drosophila whole body cells, Comet images of DNA strand breaks of control (A), (B) and (C) and (D) DNA damaged after exposure to sodium sulphite, boric acid and benzoic acid respectively.

Table 2 Detection of DNA damage by the comet assay, assessed as tail moment (TM) in whole body cells of white eye adult Drosophila treated with the sodium sulphite, boric acid and benzoic acid.

\begin{tabular}{lccccc}
\hline Group & Tailed \% & Untailed \% & Tails length $\boldsymbol{\mu m}$ & Tail DNA \% & Tail moment \\
\hline Control & 2 & 98 & $1.29 \pm 0.10$ & 1.45 & 1.83 \\
\hline $\begin{array}{l}\text { P.N P.N } \\
\begin{array}{l}\text { Sodium } \\
\text { Sulphite }\end{array}\end{array}$ & 17 & 83 & $6.90 \pm 0.50^{*}$ & 5 & 34.56 \\
\hline $\begin{array}{l}\text { S.B } \\
\text { Boric Acid }\end{array}$ & 10 & 90 & $5.34 \pm 0.19^{*}$ & 4.15 & 16.12 \\
\hline $\begin{array}{l}\text { Benzoic } \\
\text { Acid }\end{array}$ & 25 & 75 & $8.5 \pm 0.58^{* *}$ & 7.11 & 60.15 \\
\hline
\end{tabular}

This study evaluated the potential genotoxicity and carcinogenicity of three food additives commonly used in food industry using SMART test on Drosophila melanogaster system and comet assay. The obtained results clearly reveals the genotoxic potential of the tested food preservatives. Formation of tumors in Drosophila SMART assay is a strong indication for Loss of heterozygosity $(\mathrm{LOH})$ in somatic cells. The mechanism might involve mutation, chromosome loss or somatic recombination. Further studies will be carried out to investigate the mechanism of $\mathrm{LOH}$. The use of alternative small organisms as models in toxicology has grown tremendously in the last decade. Drosophila has always been a premier model for both developmental biologists and geneticists, however, several recent toxicology studies have used this organism. Currently Drospohila is being used in studies of a number of priority environmental contaminants and toxicants (rand et al., 2015). The striking resemblance between human and Drosophila genes and the presence of numerous highly conserved genes and pathways controlling development of stress response across these two divergent species suggests that the genotoxic potential of the tested might have the same effect on human that cannot be ignored (Mackay and Anholt, 2006; Misra et al., 2011; Sykiotis and Bohmann,2010). In a previous study, Sarikaya and Solak (2003) evaluated the genotoxicity of benzoic acid using $D$. melanogaster wing SMART test. They found a positive correlation between total mutation and the number of mutated wings. The genotoxicity of four benzyl derivatives; benzaldehyde, benzyl acetate, benzyl alcohol, and benzoic acid was evaluated by Demir et al. (2008) using different concentrations $(0.1,0.5,1,10,25$ and $50 \mathrm{mM})$ with the aid of the same test. They ordered these compounds according to their genotoxic effect as benzaldehyde, benzyl acetate, benzyl alcohol, and benzoic. Njagi and Gopalan (1982) reported that sodium sulphite and sodium benzoate inhibit DNA synthesis and induce the anaphase bridges, chromosome condensation in Vicia faba root meristems. The genotoxicity of sodium benzoate on human lymphocytes was studied by (Patel and Ramani, 2017) using chromosomal aberration and sister chromatid exchange assay. They concluded that these compounds can induce chromosomal aberration, sister chromatid exchange and decrease the cell cycle proliferation index at $0.5,1$ and $1.5 \mathrm{mg} / \mathrm{ml}$ concentrations. Benzoic acid used at a concentration of $500 \mu \mathrm{g} / \mathrm{ml}$ was also found to decrease the mitotic index and increase the frequency of chromosomal aberration in human lymphocytes (Yelmaz, 2009; Al-Tai, 2014). The impact of sodium metabisulphite and boric acid on somatic cells of Vicia faba L. was studied by (Pandey and Upadhyay, 2007). They found a significant decrease in mitotic index and an increase in the abnormality percentage with increasing concentrations. They were also found to stimulate a significant decrease in mitotic index in human lymphocytes (Meng and Zang, 1992; Rencuzogullari $\boldsymbol{e}$ al., 2001). Results obtained from comet assay have backed up the genotoxic potential of these food additives considering the significant amount of DNA damage in cells treated by the tested compounds compared to negative control. The mechanism of boric acid and borax genotoxicity was assessed in zebrafish Denio rerio after $24,48,72$ and 96-hours acute exposure level to 1, 4, 16, 64 $\mathrm{mg} / \mathrm{l}$ of each of the tested compounds in semi-static bioassay experiment. Peripheral erythrocytes were drawn from caudal vein and subjected to Comet assay to assess genotoxicity. The amount of DNA damage caused by boric acid was found to be concentration dependent, while that caused by borax was in both concentration and time dependent manner (Gülsoy et al., 2015). A significant increase in mean tail intensity and mean tail length were observed by Yilmaz $e$ al. (2014) in human lymphocytes exposed to $50-500 \mu \mathrm{g} / \mathrm{ml}$ concentrations of benzoic acid. In another study, when human male germ cells were exposed to different concentrations $50,100,200$ and $500 \mu \mathrm{g} / \mathrm{ml}$ of benzoic acid, the results indicated that the concentrations starting from $200 \mu \mathrm{g} / \mathrm{ml}$ showed a significant increase in tail DNA\%, tail length and tail moment (Pandir 2016). Meng et al. (2004) investigated the in vivo effects of sodium sulfite and sodium bisulfite on various organs (brain, lung, heart, liver, stomach, spleen, thymus, bone marrow and kidney) of male mice. They found significant increases in DNA damage providing further evidence for a systemic toxic activity of sulfur dioxide derivatives. 


\section{CONCLUSION}

It can be safely concluded from the present and previous work that all of the tested compounds has a noticeable genotoxic potential that cannot be ignored while using such chemicals in the food industry. Further thorough investigations are recommended before continuing using these substances in food and cosmetics as additives.

\section{REFERENCES}

Al-Tai, E.M.F. (2014)..Protective Effect of pomegranate molasses (PM) Against Genotoxicity Induced by Benzoic acid (E-210) in human lymphocytes in vitro. Nature and Science, 12 (11),13-16. http://www.sciencepub.net/nature3

Barranco, W.T., Eckhert, C.D., (2004). Boric acid inhibits human prostate cancer $\begin{array}{lllll}\text { cell proliferation. } \quad \text { Cancer } & \text { Lett., } & \text { 216(1), }\end{array}$ https://doi.org/10.1016/j.canlet.2004.06.001

Brendler-Schwaab, S., Andreas, H., Stefan, P. \& Speit, G. (2005). The in vivo comet assay: use and status in genotoxicity testing. Mutagenesis, 20(4), 245-254, https://doi.org/10.1093/mutage/gei033

Demir, E., Kocaoğlu, S., \& Kaya, B. (2008). Genotoxicity testing of four benzyl derivatives in the Drosophila wing spot test. Food Chem. Toxicol., 46(3), 103441. https://doi.org/10.1016/j.fct.2007.10.035

Demir, E., Kaya, B., Marcos, R., Kocaoğlu Cenkci, S., \& Cetin, H. (2013) Investigation of the genotoxic and antigenotoxic properties of essential oils obtained from two Origanum species by Drosophila wing SMART assay. Turkish Journal of Biology, 37(2), 129 - 138. https://doi.org/10.3906/biy-1205-64

Eeken, J. CJ., Klink, I., Bert, L., Veen, V., Pastink, A., \& Ferro, W. (2002). Induction of Epithelial Tumors in Drosophila melanogaster Heterozygous for the Tumor Suppressor Gene wts. Environ. Mol. Mutagenesis, 40(4), 277-282. https://doi.org/10.1002/em.10119.

FlyBase: anatomical data, images and queries. (2006). Nucleic Acids Res., 34(1), 484-488. https://doi.org/10.1093/nar/gkj068

Gülsoy, N., Yavas, C., \& Mutlu, Ö. (2015). Genotoxic effects of boric acid and boraxin in Zebra fish, Danio rerio using alkaline comet assay. EXCLI. J., 14, 890-899. http://dx.doi.org/10.17179/excli2015-404

Ishidate, J. R.M., Sofuni, T., Yoshikawa, K., Hayashi, M., Nohmi, T., Sawada, M. \& Matsuoka, A. (1984). Primary mutagenicity screening of food additives currently used in Japan. Food Chem. Toxicol., 22(8), 623-636. https://doi.org/10.1016/0278-6915(84)90271-0

Justice, R.W., Zilian, O., Woods, D.F., Noll M, et al. (1995). The Drosophila tumor suppressor gene warts encodes a homolog of human myotonic dystrophy kinase and is required for the control of cell shape and proliferation. Genes Dev., 9, 534-546.

https://doi.org/10.1101/gad.9.5.534

Lindsley, D.L., Zimm, G.G. (eds). (1992) The genome of Drosophila melanogaster. San Diego,CA: Academic Press. https://doi.org/10.1002/bies.950150612

Mackay, T.F., Anholt, R.R., (2006). Of flies and man: Drosophila as a model for human complex traits. Аnпи. Rev. Genomics Hum. Genet., 7, 339-367. https://doi.org/10.1146/annurev.genom.7.080505.115758

Meng, Z.\& Zhang, L. (1992 ). Cytogenetic damage induced in human lymphocytes by sodium bisulfite. Mutation Res., 298 (2), 63-69. https://doi.org/10.1016/0165-1218(92)90030-4

Meng Ziqiang, Guohua Qin, Bo Zhang, \& Juli, B. (2004) . DNA damaging effects of sulfur dioxide derivatives in cells from various organs of mice. Mutagenesis, 19 (6), 465-468. https://doi.org/10.1093/mutage/geh058

Misra, J.R., Horner, M.A., Lam, G., \& Thummel, C.S. (2011). Transcriptional regulation of xenobiotic detoxification in Drosophila Genes \& development, 25, 1796-1806 http://doi.org/10.1101/gad.17280911

Mukhopadhyay, I., Chowdhuri, D.K., Bajpayee, M., \& Dhawan, A. (2004). Evaluation of in vivo genotoxicity of cypermethrin in Drosophila melanogaster using the alkaline Comet assay. Mutagenesis, 19 (2), 85- 90. https://doi.org/10.1093/mutage/geh007

Nepomuceno, J.C. (2015). Using the Drosophila melanogaster to assessment carcinogenic agents through the test for detection of epithelial tumor clones (Warts). Adv. Tech. Biol. Med., 3(3), 149. http://doi.org/10.4172/23791764.1000149

Njagi, G.D.E.\& Gopalan, H.N.B. (1982). Cytogenetic effects of the food preservatives - Sodium benzoate and sodium sulphite on Vicia faba root meristems. Mutation Res./ Genetic Toxicol., 102(3), 213-219. https://doi.org/10.1016/0165-1218(82)90131-8

Olorunfemi, D., Duru, E. \& Felix Okieimen, F. (2012). Induction of chromosome aberrations in Allium cepa L. root tips on exposure to ballast water. Caryologia: International Journal of Cytology, Cytosystematics and Cytogenetics, 65(2), 147-151. https://doi.org/10.1080/00087114.2012.711676

Pandey, R.M., Upadhyay, S. (2007). Impact of Food Additives on Mitotic Chromosomes of Vicia faba L. Caryologia, 60(4), 309-314.

https://doi.org/10.1080/00087114.2007.10797952
Pandir, D. (2015). DNA damage in human germ cell exposed to the some food $\begin{array}{llll}\text { additives in } \quad \text { vitro. } & \text { Cytotechnology. } 725-733 .\end{array}$ http://doi.org/10.1007\%2Fs10616-014-9824-y

Patel, D. \& Ramani, R.. (2017). In vitro determination of genotoxic effects of sodium benzoate preservative on human peripheral blood lymphocytes. Int. $J$. Res. Biosci., 6(3), 20-26. [IJRBS]

Potter, C.J., Turenchalk, G.S., \& Xu, T. (2000). Drosophilla in cancer research Trends Genet., 16(1), 33-39. http://doi.org/10.1016/s0168-9525(99)01878-8 Rand, M.D., Montgomery, L. S., Prince, L., \& Vorojeikina, D. (2015) Developmental Toxicity Assays Using the Drosophila Model Curr. Protoc Toxicol., 59(1), 1.12.1-1.12. . http://doi.org/10.1002/0471140856.tx0112s59

Rekha, K. \& Dharman, A.K. (2011). Mitotic aberrations induced by sodium benzoate: A food additive in Allium cepa L. Plant Archives, 11(2), 945- 947. [Research gate]

Renczogullari,E.,Kayraldiz,A.,Ülah,B.,Ckmak,T.,\&Topakta,O.(2001). The cytogenetic effects of sodium metabisulfite, a food preservative in root tip cells of Allium cepa L. Turk. J. Biol., 25(4), 361-370. [Semanticscholar]

Sarikaya, R.\& Solak, K. (2003). Genotoxicity of Benzoik Asit Studued in the Drosophila melanogaster Somatic Mutation and Recombination Test (SMART). Gazi Eğitim Fakültesi, Dergisi, 23(3), 19-32. [Semanticscholar]

Shukla, A.K., Pragya, P., \& Chowdhuri, D.K. (2011). A modified alkaline Comet assay for in vivo detection of oxidative DNA damage in Drosophila melanogaster. Mutatation Res., 726(2), 222-226. https://doi.org/10.1016/j.mrgentox.2011.09.017

Sidorov, R.A, Ugnivenko, E.G., Khovanova, E.M., \& Belitsky, G.A., (2001) Induction of tumor clones in D. melanogaster wts/+ heterozygotes with chemical carcinogens. Mutation Res., 498(1-2),181-191. http://doi.org/10.1016/s1383-5718(01)00277-7

Sykiotis, G.P., Bohmann, D., (2010). Stress-Activated Cap'n'collar Transcription Factors in Aging and Human Disease . Sci, Signaling, 3(112), re3. http://doi.org/10.1126/scisignal.3112re3

Singh, N.P., McCoy, M.T., Tice, R.R., \& Schneider, E.L.. (1988). A simple technique for quantitation of low levels of DNA damage in individual Cells. Exp. Cell Res., 175(1), 184-191. http://doi.org/10.1016/0014-4827(88)90265-0

Tice, R.R., Agurell, E., Anderson, D., Burlinson, B., Hartmann, A., Kobayashi, H., et al.; (2000). Single cell gel/comet assay: guidelines for in vitro and in vivo genetic toxicology testing. Environmental and Molecular Mutagenesis, 35(3), 206-221. $\quad$ https://doi.org/10.1002/(SICI)1098- $\quad 2280(2000) 35: 3<206:$ :aidem8>3.0.co; $2-\mathrm{j}$

Vasconcelos, M.A., Orsolin, P.C., Silva-Oliveira, R.G., Nepomuceno, J.C., \& Spanó, M.A., (2017). Assessment of the carcinogenic potential of high intensesweeteners through the test for detection of epithelial tumor clones (warts) in Drosophila melanogaster. Food Chem. Toxicol., 101, 1-7. https://doi.org/10.1016/j.fct.2016.12.028

Wei, Y., Yuan, F.J., Zhou, W.B., Wu, L., Chen, L., Wang, J.J., \& Zhang, Y.S (2016). Borax-induced apoptosis in HepG2 cells involves p53, Bcl-2, and Bax Genet. Mol. Res., 15(2). https://doi.org/10.4238/gmr.15028300

Y1lmaz, S., Fatma, U., \& Deniz, Y. (2009). The in vitro genotoxicity of benzoic acid in human peripheral blood lymphocytes. Cytotechnology, 60(1-3), 55-61. https://dx.doi.org/10.1007\%2Fs10616-009-9214-Z

Yilmaz, S., Unal, F., Yüzbașığlu, D., \& Celik, M.. (2014). DNA damage in human lymphocytes exposed to four food additives in vitro. Toxicol. Ind. Health, 30 (10), 926-37. https://doi.org/10.1177/0748233712466132 